\title{
Epidemiology and Diagnostic Perspectives of Dermatophytoses
}

\author{
Monise Fazolin Petrucelli ${ }^{1}{ }^{\mathbb{D}}$, Mariana Heinzen de Abreu ${ }^{1}$, Bruna Aline Michelotto Cantelli ${ }^{1}$, \\ Gabriela Gonzalez Segura ${ }^{1}$, Felipe Garcia Nishimura ${ }^{1}$, Tamires Aparecida Bitencourt ${ }^{1,2,3}$, \\ Mozart Marins ${ }^{1}$ (D) and Ana Lúcia Fachin ${ }^{1, *(D)}$ \\ 1 Biotechnology Unit, Unaerp, Av. Costábile Romano, 2201, Ribeirão Preto SP 14096-900, Brazil; \\ mofazolin@gmail.com (M.F.P.); mariheinzen@gmail.com (M.H.d.A.); brucantelli@hotmail.com (B.A.M.C.); \\ gabrielagonzalezsegura@hotmail.com (G.G.S.); felipegnishi@hotmail.com (F.G.N.); \\ tabitencourt@yahoo.com.br (T.A.B.); mmarins@gmb.bio.br (M.M.) \\ 2 Department of Genetics, Ribeirão Preto Medical School, University of São Paulo, \\ Ribeirão Preto SP 14049-900, Brazil \\ 3 Department of Biochemistry and Immunology, Ribeirão Preto Medical School, University of São Paulo, \\ Ribeirão Preto SP 14049-900, Brazil \\ * Correspondence: afachin@unaerp.br; Fax: +55-16-3603-7030
}

Received: 15 October 2020; Accepted: 2 November 2020; Published: 23 November 2020

\begin{abstract}
Dermatophytoses affect about $25 \%$ of the world population, and the filamentous fungus Trichophyton rubrum is the main causative agent of this group of diseases. Dermatomycoses are caused by pathogenic fungi that generally trigger superficial infections and that feed on keratinized substrates such as skin, hair, and nails. However, there are an increasing number of reports describing dermatophytes that invade deep layers such as the dermis and hypodermis and that can cause deep infections in diabetic and immunocompromised patients, as well as in individuals with immunodeficiency. Despite the high incidence and importance of dermatophytes in clinical mycology, the diagnosis of this type of infection is not always accurate. The conventional methods most commonly used for mycological diagnosis are based on the identification of microbiological and biochemical features. However, in view of the limitations of these conventional methods, molecular diagnostic techniques are increasingly being used because of their higher sensitivity, specificity and rapidity and have become more accessible. The most widely used molecular techniques are conventional PCR, quantitative PCR, multiplex PCR, nested, PCR, PCR-RFLP, and PCR-ELISA. Another promising technique for the identification of microorganisms is the analysis of protein profiles by MALDI-TOF MS. Molecular techniques are promising but it is necessary to improve the quality and availability of the information in genomic and proteomic databases in order to streamline the use of bioinformatics in the identification of dermatophytes of clinical interest.
\end{abstract}

Keywords: deep infections; MALDI-TOF MS; mycological diagnosis; PCR; Trichophyton rubrum

\section{Epidemiology of Infections Caused by Dermatophytes}

Dermatophytoses are mycoses caused by pathogenic fungi that generally trigger superficial infections in animals and particularly in humans. These dermatophytoses are mainly caused by filamentous fungi that can invade and feed on keratinized substrates [1] such as skin, hair, and nails [2].

The group of dermatophytes comprises 52 keratin-degrading species divided into nine genera: Trichophyton, Microsporum, Epidermophyton, Arthroderma, Lopophyton, Nannizia, Ctenomyces, Guarromyces, and Paraphyton [3]. Among the fungi causing dermatophytoses in humans, the filamentous fungus Trichophyton rubrum is the main causative agent of cutaneous infections of the feet, nails, and body [4]. 
Infections caused by dermatophytes are called "tineas" and are classified according to the affected site, as shown in Table 1. Infections of the scalp, called tinea capitis, are more common in children, while other tineas more commonly affect postpubertal individuals. The hormonal changes that occur after puberty induce the secretion of acids by sebaceous glands, which, in turn, reduce the incidence of tinea capitis but not of other mycoses. Onychomycoses prevalence increases with, for instance, age. [5]

Table 1. Main types of "tineas".

\begin{tabular}{|c|c|c|c|}
\hline Tinea & Main Dermatophyte & Site of Infection & Reference \\
\hline Tinea corporis & $\begin{array}{c}\text { Trichophyton rubrum } \\
\text { T. tonsurans } \\
\text { Microsporum canis }\end{array}$ & Body (chest, face, arms, and/or legs) & [6] \\
\hline $\begin{array}{l}\text { Tinea pedis } \\
\text { (athlete's foot) }\end{array}$ & $\begin{array}{c}\text { T rubrum } \\
\text { T. interdigitale } \\
\text { Epidermophyton floccosum }\end{array}$ & Foot (soles or interdigital spaces) & [7] \\
\hline Tinea capitis & $\begin{array}{c}\text { T. tonsurans } \\
\text { Microsporum canis } \\
\text { Trichophyton violaceum } \\
\text { Trichophyton soudanense }\end{array}$ & Scalp & {$[8,9]$} \\
\hline Tinea cruris & T. rubrum & Groin folds & [10] \\
\hline $\begin{array}{l}\text { Tinea unguium } \\
\text { (onychomycosis) }\end{array}$ & $\begin{array}{c}\text { T. rubrum } \\
\text { T. interdigitale }\end{array}$ & Nails & [11] \\
\hline
\end{tabular}

Dermatophytoses affect individuals worldwide but their incidence is higher in tropical countries because of high temperatures and humidity [12]. Factors that influence the development of dermatophytoses include age, sex, season of year, socioeconomic and cultural conditions, and geographic location [13]. It is estimated that about 10 to $15 \%$ of individuals are contaminated with dermatophytes at some point in their life [14]. According to data from the World Health Organization (WHO), dermatophytoses affect about $25 \%$ of the world population [15] and 30 to $70 \%$ of adults are asymptomatic carriers of these diseases. In Western countries, 80 to $90 \%$ of onychomycosis cases are primarily caused by dermatophytes, with $5-17 \%$ being due to yeasts and $2-3 \%$ to non-dermatophyte molds. In southern European countries, dermatophytes are the causative agents of 40 to $68 \%$ of cases, with $21-55 \%$ being due to yeasts. In Asian and Middle Eastern countries, dermatophytes account for 40 to $48 \%$ of cases, with $43-46 \%$ of infections being caused by yeasts and $8-11 \%$ by non-dermatophyte molds. Comparatively, in Africa, onychomycosis-related infections are predominantly caused by yeasts [16]. The high prevalence of nail infections in North America is largely due to immigration of dermatophytes from other regions of the world such as West Africa and Southeast Asia. The global prevalence of tinea pedis is estimated at 5.5\%, accounting for 50\% of all cases of nail disease [17].

Among fungal infections that affect the nails, almost $50 \%$ are caused by dermatophytes [18]. It is estimated that tinea pedis is present in $30-70 \%$ of the world population. The condition is caused mainly by T. rubrum, T. mentagrophytes var. interdigitale and Epidermophyton floccosum, and men are more affected than women [19]. The main causative agent of tinea corporis is T. rubrum, which is responsible for 80 to $90 \%$ of infections. This prevalence is even higher in men and in children younger than 15 years $[20,21]$. The risk of onychomycosis increases with age, probably due to the presence of diabetes, poor peripheral circulation, longer exposure to pathogenic fungi, repeated nail trauma, and suboptimal immune function. A family history of onychomycosis is another risk factor [16].

Trichophyton rubrum and E. floccosum are dermatophytes found worldwide, with T. rubrum being the most common species [22]. In addition, other dermatophytes are found in specific regions such as Microsporum ferrugineum in Asia, T. megninii in Europe, and T. concentricum in South America. Despite the specificity of these species in each region, T. rubrum continues to be the main causative agent, except 
for Africa where a variety of dermatophytes exist in each microregion, with Microsporum audouinii and T. soudanense being the most common species $[4,23,24]$.

It is common to find in the literature several articles with epidemiological data from tropical regions. In Brazil, epidemiological data show a higher incidence of infections caused by T. rubrum in the southern and southeastern regions, followed by M. canis and T. mentagrophytes. On the other hand, a higher prevalence of T. tonsurans, T. rubrum, and M. canis is observed in the northeastern region [25-27].

Another example are countries on the African continent, where particularly Ethiopia, has a high number of cases of dermatophytosis, not only due to the climatic factor, but also because it is a country with low socioeconomic status, low level of hygiene and health care, and overcrowding [28-30]). India is also a country from which several articles are published, and which goes through the same problems as Ethiopia [31-33].

\section{Deep Infection Caused by Dermatophytes}

Dermatophytes generally cause superficial infections; however, there are an increasing number of reports describing dermatophytes that invade deep layers such as the dermis and hypodermis and that can spread to the lymph nodes, brain, and bloodstream, causing deep infections [34]. Some conditions are necessary for the establishment of this infection in the patient, including an immunosuppressive state, obesity, diabetes, and advanced age, in addition to other health problems [35]. Other factors related to this disease are environmental factors and a genetic predisposition [36].

Table 2 describes cases of deep infections caused by dermatophytes, highlighting the importance of the correct diagnosis and treatment of these infections.

Table 2. Case reports of deep infections caused by dermatophytes.

\begin{tabular}{ccc}
\hline Comorbidity & Symptoms & Reference \\
\hline Hepatitis C and liver cirrhosis & Subcutaneous nodules & {$[37]$} \\
\hline Human immunodeficiency virus (HIV) & Atypical, multiple or extensive lesions & {$[38]$} \\
\hline Transplant and chemotherapy patients & Nodules & {$[39]$} \\
\hline History of diabetes mellitus & Palpable nodules in the ankle & {$[40]$} \\
\hline $\begin{array}{c}\text { Patients without immunodeficiency, } \\
\text { history of onychomycosis }\end{array}$ & $\begin{array}{c}\text { Erythema, papules and nodules in the } \\
\text { submandibular area, neck, and chest }\end{array}$ & {$[41]$} \\
\hline $\begin{array}{c}\text { Use of immunosuppressive drugs } \\
\text { Patients without immunodeficiency, } \\
\text { hypertension and angina }\end{array}$ & Fungal abscesses & {$[42]$} \\
\hline $\begin{array}{c}\text { Fungal infection for 2 years, } \\
\text { onychomycosis }\end{array}$ & Red spots with secretion & {$[43]$} \\
\hline
\end{tabular}

\section{CARD 9 Mutation and Fungal Infections}

One protein that has attracted attention in invasive infections is CARD9 because of the correlation between mutations in this protein and severe infections caused by dermatophytes [45]. CARD9 is a signaling protein with a caspase recruitment domain that plays a key role in the innate and adaptive immunity. The CARD9 adapter has been shown to enable pattern recognition receptors to induce NF- $\mathrm{KB}$ and MAPK activation, an event that triggers a cascade of inflammatory cytokines and provides effective protection against microbial invasion, especially fungal infection [46]. Furthermore, [47] described the case of an individual with skin lesions and localized dermatitis on the neck and face. A skin biopsy revealed the presence of septate and pigmented hyphae characteristic of Phaeohyphomycosis. DNA was extracted from the patient because of the absence of a history of comorbidities and CARD9 deficiency was detected. 


\section{Diagnostic and Identification Methods for Dermatophytoses: from Conventional to Molecular Methods}

Diagnosis relies on the culture (positive or negative) and microscopy (distinct direct microscopy and histology, positive or negative as well). Cultures can then be identified using microscopy, MALDI-TOF MS or DNA sequencing. Molecular assays based on DNA (PCR) can provide both diagnosis and identification directly from clinical samples, depending on the assay.

\subsection{Culture, Microscopy, Histology and Molecular Assays Based on DNA}

The conventional methods most commonly used in mycology laboratories for the diagnosis of keratinophilic fungi are based on colony characteristics, microscopic morphology [48], growth requirements, and the results of physiological and biochemical tests. Morphological parameters are the colony pattern, pigmentation, and growth rate. Physiological tests evaluate the hydrolysis of urea and in vitro hair perforation capacity of the fungus. Biochemical parameters include the assimilation of sorbitol [49]. The analysis of physiological and biochemical parameters is useful to distinguish T. rubrum from T. mentagrophytes, as described by [49].

The conventional identification and diagnosis of dermatophytosis involves techniques of culture and morphological identification of the fungus or the detection of fungal elements by direct microscopy of clinical specimens. Sabouraud dextrose agar or potato dextrose agar is used for the isolation and identification of dermatophytes based in macroscopic characteristics such as colony color and surface. The medium is supplemented with antibiotics and cycloheximide, a reagent specific for the selection of this group of fungi. $[17,48,50]$.

Direct microscopy can be used as a low-cost, rapid result, and an easy-to-do office diagnostic test. However, this test lacks sensitivity and can be enhanced with the combination with histology testing, using periodic acid-Schiff (PAS), for example [17].

The isolation followed by identification by direct microscopic or histology of dermatophytes was considered as a gold standard method. However, this method is limited depending on the quality of the collected sample. For correct isolation of the infectious agent, asepsis of the lesion with $70 \%$ alcohol is necessary to eliminate other contaminants, as well as adequate techniques for collection of the affected tissue $[48,51]$. Consequently, the false-negative rate of this diagnostic method is high, about $35 \%$. In addition, it does not permit to determine the causative fungal species and its viability [17]. In the case of dermatophytes, morphological similarity and the limited or absent sporulation of some species hinder identification by these conventional methods. In addition to these factors, the culture of these species for diagnosis is a time-consuming process, with the growth of some fungi taking up to 6 weeks, delaying the identification of the causative species and the initiation of appropriate therapy [48].

In dermatophytoses, the isolation and correct identification of the causative agent are essential for the choice of adequate treatment. For example, infections caused by anthropophilic dermatophytes require shorter treatment than those caused by zoophilic dermatophyte species. On the other hand, non-dermatophyte fungal species may not respond adequately to the treatment used for dermatophytoses [48].

Some non-dermatophyte species such as Fusarium, Acremonium, and Aspergillus were identified as causative agents of onychomycoses in patients who did not respond to treatment with terbinafine or itraconazole [52]. These antifungal agents have been well established for the treatment of onychomycoses caused by dermatophytes. The wrong diagnosis or lack of identification of the causative agent in these patients may have led to the incorrect hypothesis of the existence of resistant dermatophyte strains in these cases [48]. Thus, the correct identification of the causative fungal species will help to more accurately determine the appropriate treatment, reducing cases of recurrent infections, in addition to contributing to the investigation and control of epidemics [17,48]. 
Considering the limitations of conventional methods for the identification and diagnosis of dermatophytes, molecular diagnostic techniques are increasingly being used because of their higher sensitivity and specificity and the shorter time necessary for identification of the causative agent. In addition, these methods have become more accessible. Molecular assays based on DNA can provide both diagnosis and identification of the infectious agent directly from clinical samples. Rapid and accurate identification of dermatophytes is essential for the successful treatment of patients with these infections [48].

Molecular diagnostic methods involve the extraction of DNA from the fungus present in clinical samples. The genetic material can be extracted by the traditional phenol-chloroform method or with commercial DNA extraction kits, which provide more efficient extraction. The presence of keratin in clinical sample requires digestion of this protein by enzymatic or non-enzymatic methods $[48,53]$. DNA extraction followed by the application of different methods for molecular diagnosis has advanced significantly in the last 15 years [48].

DNA sequences are very useful for this purpose and permit an accurate identification. The internal transcribed spacer polymorphisms ITS1 and ITS2 that flank the region encoding the $5.8 \mathrm{~S}$ rDNA show adequate and reliable sensitivity in distinguishing different species. In addition, the $28 \mathrm{~S}$ rDNA sequences and genes encoding topoisomerase II and chitin synthase I are used for the identification of dermatophyte species [53].

Molecular diagnostic methods that provide good sensitivity and specificity as well as fast results include the polymerase chain reaction (PCR) and real-time PCR techniques. Studies using PCR reported a rate of correct diagnoses of $74-100 \%$ [54].

Conventional PCR is the most widely used method as it provides the best cost-benefit ratio, as well as rapid detection. This technique uses primers amplifying DNA sequences that are specific for the species to be identified. Specific primers to detect any dermatophyte species in a sample (pan-dermatophyte primers) or primers that detect any fungal species (pan-fungal primers) can also be used [53]. The results are interpreted by analyzing the size of the amplicons generated on agarose gel $[48,53]$. In the study of [55] comparing the performance of different methods for the diagnosis of onychomycosis in 60 patients, the best sensitivity (> 90\%) was observed for PCR. In a similar study, [56] suggested the use of PCR as a complementary method for clinical confirmation of suspected cases of onychomycosis. In addition, [57] observed that PCR reduced the time necessary for the diagnosis of dermatophytosis from 4 weeks to $7 \mathrm{~h}$ when conventional culture growth was compared with the molecular method, confirming the rapidity and efficacy of PCR.

A post-test called nested PCR can also be used to increase the sensitivity in dermatophyte detection during the diagnosis by conventional PCR $[48,57]$. This test is a modification of the conventional PCR technique and consists of a second amplification of the fragment amplified by conventional PCR. In this method, the fragment amplified in the first PCR is used as a template for the second amplification, employing primers that only flank the region of the fragment amplified in the first reaction. The aim of this post-PCR technique is to reduce the nonspecific binding of products generated in the first PCR, increasing specificity and sensitivity [48]. Using pan-dermatophyte primers, [58] performed nested PCR for the amplification of translation elongation factor $1-\alpha($ Tef- $1 \alpha)$ in order to increase the accuracy of identification of relevant dermatophytes in samples of animals with dermatophytosis. Although they increase the sensitivity of conventional PCR, the disadvantage associated with post-PCR techniques is the high risk of contamination of the already amplified PCR products due to the manipulation of these fragments in nested PCR, in addition to prolonging the time to diagnosis $[48,53]$.

Another variant of the PCR technique called multiplex PCR allows the identification of multiple targets in a single reaction, with the benefit of saving time and speeding up the diagnosis. However, for the success of multiplex PCR, it is important to evaluate the possibility of dimerization between the primers used in order to prevent nonspecific amplification. This variant of conventional PCR increases the efficiency of detection and reduces the risk of false-negative results. Highlighted the efficiency, sensitivity, and specificity of multiplex PCR for a faster diagnosis of onychomycosis caused 
by dermatophytes and by Fusarium spp [59]. Similarly, recommended the use of multiplex PCR for the diagnosis of dermatophytic onychomycosis in cases with a negative culture or when the culture is contaminated with fast-growing fungi, a fact that renders the identification of the causal agent problematic [60].

The combination of the restriction fragment length polymorphism (RFLP) technique and PCR can also be used for the identification and discrimination of fungal species in dermatological samples. The so-called PCR-RFLP technique consists of the amplification of specific nucleic acid fragments that exhibit small genetic variations, followed by restriction enzyme analysis and identification of the fragments by gel electrophoresis [48]. This technique can also be used to investigate the composition of microbial communities in different ecological systems such as water and soil [53].

Studying 35 patients with a suspicion of onychomycosis [61] obtained $85.71 \%$ sensitivity using PCR-RFLP as the diagnostic test, suggesting that this method is more accurate in the diagnosis of onychomycosis than conventional culture. Used PCR-RFLP to evaluate inter- and intraspecific genomic variations among clinically important dermatophytes isolated from clinical samples [62].

The advantages of PCR-RFLP include its low cost and easy design, as well as the fact that no sophisticated equipment is required. However, it is a laborious technique that involves the use of restriction enzymes and identification and knowledge of the desired genetic variants, requiring more time for analysis. Thus, PCR-RFLP is generally not used for routine diagnostics [48].

An alternative assay with a higher diagnostic sensitivity than analysis by gel electrophoresis [53] is PCR-enzyme-linked immunosorbent assay (ELISA). This is a hybrid technique of PCR and ELISA; however, instead of detecting proteins as in a traditional ELISA, PCR-ELISA permits the direct detection of nucleic acids amplified by PCR [48]. This method was developed to increase the sensitivity of detection of dermatophytes in infected tissues and nails. For diagnosis, a PCR amplification with digoxygenin is first performed, generating PCR products labeled with digoxigenin that bind to biotin-labeled oligonucleotides. The biotinylated PCR products are immobilized on a microplate and are detected with anti-digoxigenin. Alternatively, hybridization of the PCR products to fluorescein-labeled oligonucleotide probes can also be performed, followed by detection with horseradish peroxidase-conjugated anti-fluorescein antibodies [48,53].

PCR-ELISA with amplification of the topoisomerase II gene and detection by hybridization using digoxigenin-labeled probes resulted in the successful identification of dermatophyte species such as T. rubrum, T. interdigitale, T. violaceum, M. canis, and E. floccosum directly in clinical samples within 24 $\mathrm{h}[53,63]$. Dermatophytes of the genus Trichophyton were also successfully identified by PCR-ELISA in epidemiological studies conducted in India using skin scrapings from 201 patients [64]. A commercial kit for the detection of dermatophytes in cases of onychomycosis, called Onychodiag, was developed based on the PCR-ELISA technique. However, this technique is not used as a routine laboratory test because of the need for elaborate manipulations and the longer time to diagnosis [48,53].

A very promising method to minimize the risks of contamination and to eliminate the need for post-PCR tests and gel electrophoresis analysis of the results is real-time PCR. This method is also used for the diagnosis of dermatophytosis $[48,53]$. Real-time PCR detects the presence of DNA or RNA, thus enabling the rapid identification especially of microorganisms. In addition to detecting infectious agents, this technique also provides quantitative data regarding the number of microorganisms present in the sample. Analysis of the results is based on the threshold cycle value $(\mathrm{Ct})$, which corresponds to the number of PCR amplification cycles at which the fluorescence generated within a reaction crosses the fluorescence threshold. Thus, the higher the amount of genetic material present in the sample, the smaller the number of cycles necessary for a positive result and the greater the emitted fluorescence; consequently, low $\mathrm{Ct}$ values will be obtained [65].

The diagnostic results obtained by real-time PCR are usually reported as positive, negative, or indeterminate [65]. The quantitative nature of the method in estimating the fungal load of a sample, for example, helps with the differentiation between infection and contamination of clinical samples based on the threshold values obtained in cases of infection. Within this context, studies suggest that 
real-time PCR can be applied successfully for the diagnosis of dermatophytosis with much higher precision compared to classical diagnostic methods [48]. Furthermore, evaluating dermatophytes in nail samples, [66] showed that real-time PCR detected the presence of dermatophytes in samples that tested negative by conventional PCR, suggesting a higher diagnostic sensitivity of the former.

In an attempt to increase the diagnostic response, real-time PCR can be performed as described by [67], who indicates multiplex RT-PCR as the fastest and most efficient method for the identification of dermatophyte species in clinical samples, or using pan-dermatophyte primers as described by [66] for the diagnosis of dermatophytes in nail samples. Commercial kits designed to facilitate the identification of dermatophytes by real-time PCR have also been developed. One example is the Derma Genius ${ }^{\circledR}$ multiplex kit for the accurate and rapid identification of T. rubrum, T. interdigitale, and Candida albicans in nails [68].

Taken together, it is evident that the development of molecular techniques has brought several benefits, permitting a better diagnosis of dermatophytoses and more appropriate treatment for patients with these diseases.

\subsection{MALDI-TOF-MS}

Another promising technique for the identification of microorganisms is the fingerprint of a protein extract by matrix-assisted laser desorption/ionization time of flight mass spectrometry (MALDI-TOF MS). This method is applied to the identification of a wide range of species [69-74], including dermatophytes [69-78] but until now, is not used in clinical diagnostic method for dermatophytosis. In addition, this approach has drastically reduced the response times in routine clinical laboratories $[72,74,77,79]$. MALDI-TOF MS uses the characteristic fingerprint of a protein to identify a specific microorganism by combining species-specific protein patterns included in a comprehensive reference spectra library [80]. Hence, the identity of microorganisms can be established at the species level in mycology $[75,81]$.

In the case of fungi in general, identification by MALDI-TOF MS can be compromised if the sample is contaminated with culture medium, especially when fungal colonies are present and cannot be separated from the agar [79]. This limitation is also discussed by [82], which suggested the use of a new medium called Id-Fungi plates (IDFP) from Conidia ${ }^{\circledR}$.

The use of this technique for the study of dermatophytes is more complex because of the variable phenotypes of these fungi, which can result in variations of the protein spectra; this heterogeneity is affected by the growth conditions and by the mycelial zone examined (concomitant presence of different fungal structures, hyphae and/or conidia, in the same culture) $[83,84]$. However, the main limitation for the identification of dermatophytes is the inadequate representation of dermatophyte species in the reference spectra libraries of the current commercial MALDI-TOF MS identification systems. Identification by MALDI-TOF MS still requires the successful growth of fungus in culture. However, even in the case of adequate sampling, dermatophytes exhibit relative low sensitivity, with approximately $30 \%$ of the culture results being false negative $[85,86]$.

The main concern associated with the identification of pathogenic fungi by MALDI-TOF MS are the similarities of molecular components, which can render sister species indistinguishable, for example, Trichophyton rubrum and T. violaceum or Microsporum canis and M. audouinii $[70,71,78,87]$. For each MALDI-TOF MS system, the reference database for species coverage is essential for the approach, as long as the database used in the analysis of MALDI-TOF MS is improved to include adequate spectra of different strains of each species studied [88]. Within this context, laboratories are recommended to generate and complement the mass spectra for their main local species or lineages and to register them with commercial reference libraries [89]. 
In contrast to bacteria, fungi require additional processing steps to break the cell wall, extract proteins, and inactivate the isolate [90]. These additional processing steps and limited libraries have led laboratories to develop their own methodologies and databases in an attempt to overcome the barriers to the adoption of the technique $[70,74,91]$. The time, media and culture conditions used for the strain to be identified must be the same as those used as a reference in the database used for comparison and spectral identification so that there are no changes in the microorganism protein profiles [70,92]. These limitations have prevented the widespread implementation of this technology in clinical laboratories for the identification of filamentous fungi.

Another limitation of MALDI-TOF MS is that, unlike publicly available sequence databases such as GenBank, commercial MALDI-TOF MS databases are usually exclusive to companies. Although the low identification rates for some organisms may be increased by user addition of mass spectral entries of under-represented species or strains (to cover intraspecies variability), or even by the re-addition of reference strain spectra to the library, especially those created using parallel growth conditions and preparation methods, doing so may be beyond the capacity of some laboratories [93]. A non-commercial option is available through an online identification tool that comprises more than 900 species of fungi and more than 200 genera of fungi, which allows the identification of fungi, including dermatophytes, for free thus facilitating the identification of fungi [94].

Four different commercial MALDI-TOF MS platforms for the routine identification of fungi in clinical microbiology laboratories are currently available. These platforms include the Andromas (Andromas SAS, Paris, France), Axima@ Saramis (Shimadzu/AnagnosTec, Duisburg, Germany), Bruker Biotyper (Bruker Daltonics, Bremen, Germany), and Vitek MS (bioMérieux, Marcy l'Etoile, France) systems [95].

The reported identification rates of dermatophytes by MALDI-TOF MS range from $13.5 \%$ to $100 \%$ [79]. However, the efficiency of this technique depends primarily on the standard library provided by the manufacturer or a supplementary library of the manufacturer. The use of these standard libraries supports the reported variable findings, for example, expansion of the library improves the accuracy of identification of dermatophytes by MALDI-TOF MS [70,78,79]. Effective identification of dermatophyte species depends on the number and variety of isolates available in the reference spectral library $[70,72,78,79]$.

Table 3 summarizes the main advantages and disadvantages of each method for the identification and diagnosis of the dermatophytes discussed in this article. 
Table 3. Main advantages and disadvantages of the identification and diagnostic methods used for dermatophytes.

\begin{tabular}{|c|c|c|c|}
\hline Methods of Identification/Diagnosis & Advantages & Disadvantages & Reference \\
\hline $\begin{array}{l}\text { Conventional (culture followed by direct } \\
\text { microscopy or histology) }\end{array}$ & $\begin{array}{l}\text { Low cost of materials } \\
\text { Well-established standard method }\end{array}$ & $\begin{array}{l}\text { Time-consuming process to obtain the result } \\
\text { High false-negative rate }\end{array}$ & {$[48,51,96]$} \\
\hline Conventional PCR & $\begin{array}{l}\text { Better cost-benefit ratio } \\
\text { Rapid detection }\end{array}$ & $\begin{array}{l}\text { Post-PCR tests might be necessary to } \\
\text { complement the diagnosis }\end{array}$ & [53] \\
\hline Nested PCR & $\begin{array}{c}\text { Reduces nonspecific binding of PCR } \\
\text { products } \\
\text { More specific results } \\
\text { Good sensitivity }\end{array}$ & $\begin{array}{l}\text { High risk of contamination } \\
\text { Prolongs the time to diagnosis }\end{array}$ & {$[48,53]$} \\
\hline Multiplex PCR & $\begin{array}{l}\text { Identification of multiple targets in the } \\
\text { same reaction } \\
\text { Time saving and rapid diagnosis } \\
\text { Higher detection efficacy } \\
\text { Reduces the risk of false-negative results }\end{array}$ & $\begin{array}{l}\text { Possibility of nonspecific binding } \\
\text { between primers }\end{array}$ & [48] \\
\hline PCR-RFLP & $\begin{array}{l}\text { Low cost } \\
\text { Does not require sophisticated equipment }\end{array}$ & $\begin{array}{l}\text { Use of restriction enzymes is necessary } \\
\text { Requires more time for diagnostic analysis } \\
\text { Not commonly used for diagnosis }\end{array}$ & [48] \\
\hline PCR-ELISA & $\begin{array}{l}\text { Higher sensitivity than techniques that use } \\
\text { analysis by gel electrophoresis }\end{array}$ & $\begin{array}{c}\text { Elaborate manipulations are necessary } \\
\text { Requires more time for diagnostic analysis } \\
\text { Not commonly used for diagnosis }\end{array}$ & {$[48,53]$} \\
\hline Real-time PCR & $\begin{array}{c}\text { Low risk of contamination } \\
\text { Post-PCR tests are not required } \\
\text { Rapid identification } \\
\text { Quantitative detection }\end{array}$ & $\begin{array}{l}\text { Specific equipment is necessary } \\
\text { Higher cost than conventional PCR }\end{array}$ & {$[48,53,65]$} \\
\hline MALDI- TOF MS & $\begin{array}{l}\text { Identification of the microorganism at the } \\
\text { genus, species, and strain level }\end{array}$ & $\begin{array}{l}\text { Difficulty of access or incomplete } \\
\text { information of some dermatophyte species } \\
\text { in databases used for identification } \\
\text { Sister species might be indistinguishable } \\
\text { because of similar molecular components }\end{array}$ & {$[70-72,74,75,77,79,81,85-87,93]$} \\
\hline
\end{tabular}




\section{The Potential of Molecular Approaches for the Study of Dermatophytes}

A vast range of molecular approaches exist in clinical mycology. These approaches are not only limited to diagnostic tests but can also be used for prospecting new antifungal compounds for the treatment of these diseases, as done by [97-99], as well as for the identification of conserved regions that contribute to the virulence of these pathogens as described by [100], enabling the discovery of new therapeutic targets. Moreover, technologies for large-scale transcriptome analyses such as RNAseq and microarray have contributed to a better understanding of dermatophyte-host interactions at the molecular level [101,102], in addition to providing new insight into the effect of commercial antifungals such as terbinafine on species such as T. rubrum. Modulation of 277 differentially expressed genes was observed in co-cultures of the dermatophyte T. rubrum with the HaCat keratinocyte cell line in the presence of terbinafine. Approximately $28 \%$ of these genes have been studied in other dermatophytes but not in T. rubrum, thus contributing to the elucidation of the functions of these genes in this species and of the response mechanisms to antifungal agents. In addition, modulation of different genes with an important role in the biosynthesis and transport of ergosterol, such as ERG1, ERG5, ERG11, CYP51, and CYP61, was demonstrated [103].

\section{Future Perspectives}

Major advances have been made over the years in the identification and diagnosis of dermatophytes. However, some limitations, such as the lack of a complete database for the identification of pathogenic fungi, are still an obstacle. The establishment of an extensive online database containing the molecular profiles of fungal species involved in human diseases, with the possibility of inclusion of additional information by users, would be a major advance in this field. This requires the development of reliable algorithms that allow the rapid consultation of thousands of reference molecular profiles and easy access for everyone.

Author Contributions: Conceptualization, M.F.P., M.H.d.A. and A.L.F.; writing-original draft preparation, M.F.P., M.H.d.A. G.G.S., B.A.M.C., F.G.N., T.A.B., A.L.F., M.M. writing-review and editing; M.F.P., M.H.d.A. G.G.S., B.A.M.C., F.G.N., T.A.B., A.L.F., M.M., A.L.F. designed the project, supervised the research, contributed reagents/materials/analysis tools, and wrote the manuscript. All authors have read and agreed to the published version of the manuscript.

Funding: This study was supported by grants from Fundação de Amparo à Pesquisa do Estado de São Paulo (FAPESP, 2019/10514-8) and CAPES (Ph.D. fellowships).

Acknowledgments: We thank S.C. França and the staff of the Biotechnology Unit-UNAERP for general support.

Conflicts of Interest: The authors declare no conflict of interest.

\section{References}

1. Gnat, S.; Łagowski, D.; Nowakiewicz, A.; Zięba, P. The host range of dermatophytes, it is at all possible? Phenotypic evaluation of the keratinolytic activity of Trichophyton verrucosum clinical isolates. Mycoses 2019, 62, 274-283. [CrossRef] [PubMed]

2. Khurana, A.; Sardana, K.; Chowdhary, A. Antifungal resistance in dermatophytes: Recent trends and therapeutic implications. Fungal Genet. Biol. 2019, 132, 103255. [CrossRef] [PubMed]

3. Mercer, D.K.; Stewart, C.S. Keratin hydrolysis by dermatophytes. Med. Mycol. 2019, 57, 13-22. [CrossRef] [PubMed]

4. Antuori, A.; Fernández, G.; Fernández, A.; Alcaide, M.; Boada, A.; Bielsa, M.I.; Romaní, N.; Matas, L. Epidemiology of dermatophytic infections between 2008 and 2017 in Barcelona, Spain. Enferm. Infecc. Microbiol. Clin. 2019, 37, 642-647. [CrossRef]

5. Bhavsar Hitendra, K.; Modi Dhara, J.; Sood Nidhi, K.; Shah Hetal, S. A Study of Superficial Mycoses With Clinical Mycological Profile in Tertiary Care Hospital in Ahmedabad, Gujarat. Natl. J. Med. Res. 2012, 2, 160-164.

6. Leung, A.K.; Lam, J.M.; Leong, K.F.; Hon, K.L. Tinea corporis: An updated review. Drugs Context 2020, 9, 1-12. [CrossRef] 
7. Woo, T.E.; Somayaji, R.; Haber, R.M.; Parsons, L. Diagnosis and Management of Cutaneous Tinea Infections. Adv. Skin Wound Care 2019, 32, 350-357. [CrossRef]

8. Grigoryan, K.V.; Tollefson, M.M.; Olson, M.A.; Newman, C.C. Pediatric tinea capitis caused by Trichophyton violaceum and Trichophyton soudanense in Rochester, Minnesota, United States. Int. J. Dermatol. 2019, 58, 912-915. [CrossRef] [PubMed]

9. Leung, A.K.C.; Hon, K.L.; Leong, K.F.; Barankin, B.; Lam, J.M. Tinea Capitis: An Updated Review. Recent Pat. Inflamm. Allergy Drug Discov. 2020, 14, 58-68. [CrossRef]

10. Bishnoi, A.; Mahajan, R. Tinea cruris. In Diagnostics to Pathogenomics of Sexually Transmitted Infections; wiley: Hoboken, NJ, USA, 2018; pp. 329-340. ISBN 9781119380924.

11. Asz-Sigall, D.; Tosti, A.; Arenas, R. Tinea Unguium: Diagnosis and Treatment in Practice. Mycopathologia 2017, 182, 95-100. [CrossRef] [PubMed]

12. Taplin, D. Dermatophytosis in Vietnam. Cutis 2001, 67, 19-20.

13. Iorio, R.; Cafarchia, C.; Capelli, G.; Fasciocco, D.; Otranto, D.; Giangaspero, A. Dermatophytoses in cats and humans in central Italy: Epidemiological aspects. Mycoses 2007, 50, 491-495. [CrossRef]

14. Pires, C.A.A.; da Cruz, N.F.S.; Lobato, A.M.; de Sousa, P.O.; Carneiro, F.R.O.; Mendes, A.M.D. Clinical, epidemiological, and therapeutic profile of dermatophytosis. An. Bras. Dermatol. 2014, 89, 259-264. [CrossRef]

15. Sai, B.S.; Tejashree, A.; Veeranna, S.; Krishna Karthik, M. Speciation and In Vitro Activity of Four Antifungal Drugs Against Clinical Isolates of Dermatophytes By E-Test Method. Int. J. Sci. Res. 2019, 8. [CrossRef]

16. Gupta, A.K.; Stec, N. Emerging drugs for the treatment of onychomycosis. Expert Opin. Emerg. Drugs 2019, 24, 213-220. [CrossRef]

17. Gupta, A.K.; Versteeg, S.G.; Shear, N.H. Onychomycosis in the 21st Century: An Update on Diagnosis, Epidemiology, and Treatment. J. Cutan. Med. Surg. 2017, 21, 525-539. [CrossRef] [PubMed]

18. Rafat, Z.; Hashemi, S.J.; Saboor-Yaraghi, A.A.; Pouragha, B.; Taheriniya, A.; Moosavi, A.; Roohi, B.; Arjmand, R.; Moradi, A.; Daie-Ghazvini, R.; et al. A systematic review and meta-analysis on the epidemiology, casual agents and demographic characteristics of onychomycosis in Iran. J. Mycol. Med. 2019, 29, $265-272$. [CrossRef] [PubMed]

19. Dalla Lana, D.F.; Batista, B.G.; Alves, S.H.; Fuentefria, A.M. Dermatofitoses: Agentes etiológicos, formas clínicas, terapêutica e novas perspectivas de tratamento. Clin. Biomed. Res. 2016, 36, 230-241. [CrossRef]

20. Seebacher, C.; Bouchara, J.-P.; Mignon, B. Updates on the Epidemiology of Dermatophyte Infections. Mycopathologia 2008, 166, 335-352. [CrossRef] [PubMed]

21. Piggott, C.D.S.; Friedlander, S.F. Dermatophytes and Other Superficial Fungi. In Principles and Practice of Pediatric Infectious Diseases: Fourth Edition; Elsevier Inc.: Amsterdam, The Netherlands, 2012; pp. 1246-1250.e2. ISBN 9781437720594.

22. Cordeiro, L.V. Perfil Epidemiológico De Dermatofitoses Superficiais Em Pacientes Atendidos Em Um Laboratório Da Rede Privada De João Pessoa-Pb; Universidade Federal Da Paraíba: João Pessoa, Brazil, 2015.

23. Hayette, M.P.; Sacheli, R. Dermatophytosis, Trends in Epidemiology and Diagnostic Approach. Curr. Fungal Infect. Rep. 2015, 9, 164-179. [CrossRef]

24. Jha, B.; Bhattarai, S.; Sapkota, J.; Sharma, M.; Bhatt, C.P. Dermatophytes in Skin, Nail and Hair among the Patients Attending Out Patient Department. J. Nepal Health Res. Counc. 2019, 16, 434-437. [CrossRef]

25. Teixera, N.; Peres, D.A.; Rossi, A. Dermatófitos: Interação patógeno-hospedeiro e resistência a antifúngicos. An. Bras. Dermatol. 2010, 85, 657-667.

26. Silva-Rocha, W.P.; de Azevedo, M.F.; Chaves, G.M. Epidemiology and fungal species distribution of superficial mycoses in Northeast Brazil. J. Mycol. Med. 2017, 27, 57-64. [CrossRef]

27. de Albuquerque Maranhão, F.C.; Oliveira-Júnior, J.B.; dos Santos Araújo, M.A.; Silva, D.M.W. Mycoses in northeastern Brazil: Epidemiology and prevalence of fungal species in 8 years of retrospective analysis in Alagoas. Braz. J. Microbiol. 2019, 50, 969-978. [CrossRef]

28. Araya, S.; Tesfaye, B.; Fente, D. Epidemiology of dermatophyte and non-dermatophyte fungi infection in Ethiopia. Clin. Cosmet. Investig. Dermatol. 2020, 13, 291-297. [CrossRef]

29. Bitew, A. Dermatophytosis: Prevalence of Dermatophytes and Non-Dermatophyte Fungi from Patients Attending Arsho Advanced Medical Laboratory, Addis Ababa, Ethiopia. Dermatol. Res. Pract. 2018, 2018, 1-6. [CrossRef] [PubMed]

30. Coulibaly, O.; L'Ollivier, C.; Piarroux, R.; Ranque, S. Epidemiology of human dermatophytoses in Africa. Med. Mycol. 2017, 56, 145-161. [CrossRef] 
31. Das, S.; De, A.; Saha, R.; Sharma, N.; Khemka, M.; Singh, S.; Hesanoor Reja, A.; Kumar, P. The current Indian epidemic of dermatophytosis: A study on causative agents and sensitivity patterns. Indian J. Dermatol. 2020, $65,118-122$.

32. Kalita, J.; Sharma, A.; Bhardwaj, A.; Nag, V. Dermatophytoses and spectrum of dermatophytes in patients attending a teaching hospital in Western Rajasthan, India. J. Fam. Med. Prim. Care 2019, 8, 1418-1421.

33. Thakur, R. Epidemiology of cortico-steroid-modified tinea: Study of 100 cases in a rural tertiary care teaching hospital of Western Uttar Pradesh, India. J. Dermatology Cosmetol. 2018, 2, 1. [CrossRef]

34. Lanternier, F.; Pathan, S.; Vincent, Q.B.; Liu, L.; Cypowyj, S.; Prando, C.; Taibi, L.; Ammar-khodja, A.; Stambouli, O.B.; Guellil, B.; et al. Deep Dermatophytosis and Inherited CARD9 Deficiency. N. Engl. J. Med. 2013, 369, 1704-1714. [CrossRef]

35. Bongomin, F.; Gago, S.; Oladele, R.O.; Denning, D.W. Global and multi-national prevalence of fungal diseases-Estimate precision. J. Fungi 2017, 3, 57. [CrossRef]

36. García-Romero, M.T.; Arenas, R. New insights into genes, immunity, and the occurrence of dermatophytosis. J. Investig. Dermatol. 2015, 135, 655-657. [CrossRef]

37. Warycha, M.A.; Leger, M.; Tzu, J.; Kamino, H.; Stein, J. Deep dermatophytosis caused by Trichophyton rubrum. Dermatol. Online J. 2011, 17, 21.

38. Costa, J.E.F.; Neves, R.P.; Delgado, M.M.; Lima-Neto, R.G.; Morais, V.M.S.; Coêlho, M.R.C.D. Dermatophytosis in patients with human immunodeficiency virus infection: Clinical aspects and etiologic agents. Acta Trop. 2015, 150, 111-115. [CrossRef]

39. Kershenovich, R.; Sherman, S.; Reiter, O.; Huss, S.R.; Didkovsky, E.; Mimouni, D.; Hodak, E.; Segal, R. A Unique Clinicopathological Manifestation of Fungal Infection: A Case Series of Deep Dermatophytosis in Immunosuppressed Patients. Am. J. Clin. Dermatol. 2017, 18, 697-704. [CrossRef]

40. Kim, S.H.; Jo, I.H.; Kang, J.; Joo, S.Y.; Choi, J.H. Dermatophyte abscesses caused by Trichophyton rubrum in a patient without pre-existing superficial dermatophytosis: A case report. BMC Infect. Dis. 2016, 16, 298. [CrossRef] [PubMed]

41. Su, H.; Li, L.; Cheng, B.; Zhu, J.; Zhang, Q.; Xu, J.; Zhu, M. Trichophyton rubrum Infection Characterized by Majocchi's Granuloma and Deeper Dermatophytosis: Case Report and Review of Published Literature. Mycopathologia 2017, 182, 549-554. [CrossRef]

42. Dai, Y.; Xia, X.; Shen, H. Multiple abscesses in the lower extremities caused by Trichophyton rubrum. BMC Infect. Dis. 2019, 19, 271. [CrossRef]

43. Seo, J.-K.; Jeong, K.-H.; Shin, M.K.; Choi, J.S.; Lee, M.-H. Dermal Infection with Trichophyton rubrum in an Immunocompetent Patient. Ann. Dermatol. 2019, 31, S32. [CrossRef]

44. Zhang, M.; Jiang, L.; Li, F.; Xu, Y.; Lv, S.; Wang, B. Simultaneous dermatophytosis and keratomycosis caused by Trichophyton interdigitale infection: A case report and literature review. BMC Infect. Dis. 2019, $19,983$. [CrossRef] [PubMed]

45. Rouzaud, C.; Hay, R.; Chosidow, O.; Dupin, N.; Puel, A.; Lortholary, O.; Lanternier, F. Severe dermatophytosis and acquired or innate immunodeficiency: A review. J. Fungi 2016, 2, 4. [CrossRef]

46. Zhong, X.; Chen, B.; Yang, L.; Yang, Z. Molecular and physiological roles of the adaptor protein CARD9 in immunity review-article. Cell Death Dis. 2018, 9, 1-11. [CrossRef]

47. Vaezi, A.; Mardani, M.; Fakhim, H.; Yaghoobi, M.H.; Abtahian, Z.; Nasri, E.; Geramishoar, M.; Khodavaisy, S.; Meis, J.F.; Badali, H. Severe disseminated phaeohyphomycosis in a patient with inherited card9 deficiency. Arch. Clin. Infect. Dis. 2018, 13, 13. [CrossRef]

48. Begum, J.; Mir, N.A.; Lingaraju, M.C.; Buyamayum, B.; Dev, K. Recent advances in the diagnosis of dermatophytosis. J. Basic Microbiol. 2020, 60, 293-303. [CrossRef]

49. Ates, A.; Ozcan, K.; Ilkit, M. Diagnostic value of morphological, physiological and biochemical tests in distinguishing Trichophyton rubrum from Trichophyton mentagrophytes complex. Med. Mycol. 2008, 46, 811-822. [CrossRef]

50. Nenoff, P.; Krüger, C.; Schaller, J.; Ginter-Hanselmayer, G.; Schulte-Beerbühl, R.; Tietz, H.J. Mycology-An update Part 2: Dermatomycoses: Clinical picture and diagnostics. JDDG J. Ger. Soc. Dermatology 2014, 12, 749-777. [CrossRef] [PubMed]

51. Lipner, S.R.; Scher, R.K. Onychomycosis: Clinical overview and diagnosis. J. Am. Acad. Dermatol. 2019, 80, 835-851. [CrossRef] 
52. Baudraz-Rosselet, F.; Ruffieux, C.; Lurati, M.; Bontems, O.; Monod, M. Onychomycosis insensitive to systemic terbinafine and azole treatments reveals non-dermatophyte moulds as infectious agents. Dermatology 2010, 220, 164-168. [CrossRef]

53. Verrier, J.; Monod, M. Diagnosis of Dermatophytosis Using Molecular Biology. Mycopathologia 2017, 182, 193-202. [CrossRef] [PubMed]

54. Pihet, M.; Govic, Y. Le Reappraisal of conventional diagnosis for dermatophytes. Mycopathologia 2017, 182, 169-180. [CrossRef] [PubMed]

55. Rothmund, G.; Sattler, E.C.; Kaestle, R.; Fischer, C.; Haas, C.J.; Starz, H.; Welzel, J. Confocal laser scanning microscopy as a new valuable tool in the diagnosis of onychomycosis-Comparison of six diagnostic methods. Mycoses 2013, 56, 47-55. [CrossRef]

56. Luk, N.M.; Hui, M.; Cheng, T.S.; Tang, L.S.; Ho, K.M. Evaluation of PCR for the diagnosis of dermatophytes in nail specimens from patients with suspected onychomycosis. Clin. Exp. Dermatol. 2012, 37, $230-234$. [CrossRef]

57. Álvarez-Mosquera, I.; Hernáez, S.; Sánchez, J.; Suárez, M.D.; Cisterna, R. Diagnosis of Superficial Mycoses by a Rapid and Effective PCR Method from Samples of Scales, Nails and Hair. Mycopathologia 2018, 183, 777-783. [CrossRef]

58. Piri, F.; Zarei Mahmoudabadi, A.; Ronagh, A.; Ahmadi, B.; Makimura, K.; Rezaei-Matehkolaei, A. Assessment of a pan-dermatophyte nested-PCR compared with conventional methods for direct detection and identification of dermatophytosis agents in animals. Mycoses 2018, 61, 837-844. [CrossRef]

59. Hwee Koo, S.; Leng Teoh, Y.; Liang Koh, W.; Ochi, H.; Kye Tan, S.; Miao Fang Sim, D.; Jiang, B.; Ling Tan, A.; Yen Tan, T.; Ping Regina Lim, S. Development and validation of a real-time multiplex PCR assay for the detection of dermatophytes and Fusarium spp. J. Med. Microbiol. 2019, 68, 1641-1648. [CrossRef]

60. Dhib, I.; Fathallah, A.; Yaacoub, A.; Hadj Slama, F.; Said, M.B.; Zemni, R. Multiplex PCR assay for the detection of common dermatophyte nail infections. Mycoses 2014, 57, 19-26. [CrossRef]

61. Lubis, N.Z.; Muis, K.; Nasution, L.H. Polymerase chain reaction-restriction fragment length polymorphism as a confirmatory test for onychomycosis. Open Access Maced. J. Med. Sci. 2018, 6, 280-283. [CrossRef]

62. Mohammadi, R.; Abastabar, M.; Mirhendi, H.; Badali, H.; Shadzi, S.; Chadeganipour, M.; Pourfathi, P.; Jalalizand, N.; Haghani, I. Use of restriction fragment length polymorphism to rapidly identify dermatophyte species related to dermatophytosis. Jundishapur J. Microbiol. 2015, 8, 4-9. [CrossRef]

63. Beifuss, B.; Bezold, G.; Gottlöber, P.; Borelli, C.; Wagener, J.; Schaller, M.; Korting, H.C. Direct detection of five common dermatophyte species in clinical samples using a rapid and sensitive 24-h PCR-ELISA technique open to protocol transfer. Mycoses 2011, 54, 137-145. [CrossRef]

64. Nenoff, P.; Verma, S.B.; Vasani, R.; Burmester, A.; Hipler, U.C.; Wittig, F.; Krüger, C.; Nenoff, K.; Wiegand, C.; Saraswat, A.; et al. The current Indian epidemic of superficial dermatophytosis due to Trichophyton mentagrophytes-A molecular study. Mycoses 2019, 336-356. [CrossRef]

65. Jacobson, L.S.; McIntyre, L.; Mykusz, J. Assessment of real-time PCR cycle threshold values in Microsporum canis culture-positive and culture-negative cats in an animal shelter: A field study. J. Feline Med. Surg. 2018, 20, 108-113. [CrossRef]

66. Gong, J.; Ran, M.; Wang, X.; Wan, Z.; Li, R. Development and Evaluation of a Novel Real-Time PCR for Pan-Dermatophyte Detection in Nail Specimens. Mycopathologia 2016, 181, 51-57. [CrossRef] [PubMed]

67. Sherman, S.; Goshen, M.; Treigerman, O.; Ben-Zion, K.; Carp, M.-J.; Maisler, N.; Ehrenreich, I.B.; Kimchi, A.; Lifshitz, S.; Smollan, G.; et al. Evaluation of multiplex real-time PCR for identifying dermatophytes in clinical samples-A multicentre study. Mycoses 2017, 61, 119-126. [CrossRef]

68. Hayette, M.P.; Seidel, L.; Adjetey, C.; Darfouf, R.; Wéry, M.; Boreux, R.; Sacheli, R.; Melin, P.; Arrese, J. Clinical evaluation of the DermaGeniusR Nail real-time PCR assay for the detection of dermatophytes and Candida albicans in nails. Med. Mycol. 2019, 57, 277-283. [CrossRef]

69. De Respinis, S.; Monnin, V.; Girard, V.; Welker, M.; Arsac, M.; Cellière, B.; Durand, G.; Bosshard, P.P.; Farina, C.; Passera, M.; et al. Matrix-assisted laser desorption ionization-time of flight (MALDITOF) mass spectrometry using the Vitek MS system for rapid and accurate identification of dermatophytes on solid cultures. J. Clin. Microbiol. 2014, 52, 4286-4292. [CrossRef]

70. Theel, E.S.; Hall, L.; Mandrekar, J.; Wengenack, N.L. Dermatophyte identification using matrix-assisted laser desorption ionization-time of flight mass spectrometry. J. Clin. Microbiol. 2011, 49, 4067-4071. [CrossRef] 
71. Packeu, A.; De Bel, A.; L'Ollivier, C.; Ranque, S.; Detandt, M.; Hendrickx, M. Fast and accurate identification of dermatophytes by matrix-assisted laser desorption ionization-time of flight mass spectrometry: Validation in the clinical laboratory. J. Clin. Microbiol. 2014, 52, 3440-3443. [CrossRef]

72. L'Ollivier, C.; Cassagne, C.; Normand, A.C.; Bouchara, J.P.; Contet-Audonneau, N.; Hendrickx, M.; Fourquet, P.; Coulibaly, O.; Piarroux, R.; Ranque, S. A MALDI-TOF MS procedure for clinical dermatophyte species identification in the routine laboratory. Med. Mycol. 2013, 51, 713-720. [CrossRef]

73. Nenoff, P.; Erhard, M.; Simon, J.C.; Muylowa, G.K.; Herrmann, J.; Rataj, W.; Gräser, Y. MALDI-TOF mass spectrometry-A rapid method for the identification of dermatophyte species. Med. Mycol. 2013, 51, 17-24. [CrossRef]

74. De Respinis, S.; Tonolla, M.; Pranghofer, S.; Petrini, L.; Petrini, O.; Bosshard, P.P. Identification of dermatophytes by matrix-assisted laser desorption/ionization time-of-flight mass spectrometry. Med. Mycol. 2013, 51, 514-521. [CrossRef]

75. Erhard, M.; Hipler, U.C.; Burmester, A.; Brakhage, A.A.; Wöstemeyer, J. Identification of dermatophyte species causing onychomycosis and tinea pedis by MALDI-TOF mass spectrometry. Exp. Dermatol. 2008, 17, 356-361. [CrossRef]

76. Alshawa, K.; Beretti, J.L.; Lacroix, C.; Feuilhade, M.; Dauphin, B.; Quesne, G.; Hassouni, N.; Nassif, X.; Bougnoux, M.E. Successful identification of clinical dermatophyte and Neoscytalidium species by matrix-assisted laser desorption ionization-time of flight mass spectrometry. J. Clin. Microbiol. 2012, 50, 2277-2281. [CrossRef] [PubMed]

77. Calderaro, A.; Motta, F.; Montecchini, S.; Gorrini, C.; Piccolo, G.; Piergianni, M.; Buttrini, M.; Medici, M.C.; Arcangeletti, M.C.; Chezzi, C.; et al. Identification of Dermatophyte Species after implementation of the in-house MALDI-TOF MS database. Int. J. Mol. Sci. 2014, 15, 16012-16024. [CrossRef]

78. Karabıçak, N.; Karatuna, O.; İlkit, M.; Akyar, I. Evaluation of the Bruker Matrix-Assisted Laser Desorption-Ionization Time-of-Flight Mass Spectrometry (MALDI-TOF MS) System for the Identification of Clinically Important Dermatophyte Species. Mycopathologia 2015, 180, 165-171. [CrossRef]

79. L'Ollivier, C.; Ranque, S. MALDI-TOF-Based Dermatophyte Identification. Mycopathologia 2017, 182, $183-192$. [CrossRef] [PubMed]

80. Murray, P.R. What Is new in clinical microbiologymicrobial identification by MALDI-TOF mass spectrometry: A paper from the 2011 William Beaumont Hospital symposium on molecular pathology. J. Mol. Diagn. 2012, 14, 419-423. [CrossRef]

81. Fagerquist, C.K.; Garbus, B.R.; Miller, W.G.; Williams, K.E.; Yee, E.; Bates, A.H.; Boyle, S.; Harden, L.A.; Cooley, M.B.; Mandrell, R.E. Rapid identification of protein biomarkers of escherichia coli O157:H7 by matrix-assisted laser desorption Lonization-time-of-flight-time-of-flight mass spectrometry and top-down proteomics. Anal. Chem. 2010, 82, 2717-2725. [CrossRef]

82. Sacheli, R.; Henri, A.S.; Seidel, L.; Ernst, M.; Darfouf, R.; Adjetey, C.; Schyns, M.; Marechal, L.; Meex, C.; Arrese, J.; et al. Evaluation of the new Id-Fungi plates from Conidia for MALDI-TOF MS identification of filamentous fungi and comparison with conventional methods as identification tool for dermatophytes from nails, hair and skin samples. Mycoses 2020, 63, 1115-1127. [CrossRef] [PubMed]

83. Sanguinetti, M.; Posteraro, B. Identification of molds by matrix-assisted laser desorption ionization-time of flight mass spectrometry. J. Clin. Microbiol. 2017, 55, 369-379. [CrossRef]

84. Santos, C.; Paterson, R.R.M.; Venâncio, A.; Lima, N. Filamentous fungal characterizations by matrix-assisted laser desorption/ionization time-of-flight mass spectrometry. J. Appl. Microbiol. 2010, 108, 375-385. [CrossRef]

85. Robert, R.; Pihet, M. Conventional methods for the diagnosis of dermatophytosis. Mycopathologia 2008, 166, 295-306. [CrossRef]

86. Hay, R. Literature review. J. Eur. Acad. Dermatol. Venereol. 2005, 19, 1-7. [CrossRef]

87. de Hoog, G.S.; Dukik, K.; Monod, M.; Packeu, A.; Stubbe, D.; Hendrickx, M.; Kupsch, C.; Stielow, J.B.; Freeke, J.; Göker, M.; et al. Toward a Novel Multilocus Phylogenetic Taxonomy for the Dermatophytes. Mycopathologia 2017, 182, 5-31. [CrossRef]

88. Sanguinetti, M.; Posteraro, B. MALDI-TOF Mass Spectrometry: Any Use for Aspergilli? Mycopathologia 2014, 178, 417-426. [CrossRef]

89. Posteraro, B.; De Carolis, E.; Vella, A.; Sanguinetti, M. MALDI-TOF mass spectrometry in the clinical mycology laboratory: Identification of fungi and beyond. Expert Rev. Proteom. 2013, 10, 151-164. [CrossRef] 
90. Schulthess, B.; Ledermann, R.; Mouttet, F.; Zbinden, A.; Bloemberg, G.V.; Böttger, E.C.; Hombach, M. Use of the Bruker MALDI Biotyper for identification of molds in the clinical mycology laboratory. J. Clin. Microbiol. 2014, 52, 2797-2803. [CrossRef] [PubMed]

91. Lau, A.F.; Drake, S.K.; Calhoun, L.B.; Henderson, C.M.; Zelazny, A.M. Development of a clinically comprehensive database and a simple procedure for identification of molds from solid media by matrix-assisted laser desorption ionization-Time of flight mass spectrometry. J. Clin. Microbiol. 2013, 51, 828-834. [CrossRef]

92. Pennanec, X.; Dufour, A.; Haras, D.; Réhel, K. A quick and easy method to identify bacteria by matrix-assisted laser desorption/ionisation time-of-flight mass spectrometry. Rapid Commun. Mass Spectrom. 2010, 24, 384-392. [CrossRef]

93. Patel, R. A moldy application of MALDI: MALDI-ToF mass spectrometry for fungal identification. J. Fungi 2019, 5, 4. [CrossRef]

94. Normand, A.C.; Becker, P.; Gabriel, F.; Cassagne, C.; Accoceberry, I.; Gari-Toussaint, M.; Hasseine, L.; De Geyter, D.; Pierard, D.; Surmont, I.; et al. Validation of a new web application for identification of fungi by use of matrix-assisted laser desorption ionization-time of flight mass spectrometry. J. Clin. Microbiol. 2017, 55, 2661-2670. [CrossRef]

95. Hedayati, M.T.; Ansari, S.; Ahmadi, B.; Armaki, M.T.; Shokohi, T.; Abastabar, M.; Er, H.; Özhak, B.; Öğünç, D.; Ilkit, M.; et al. Identification of clinical dermatophyte isolates obtained from Iran by matrix-assisted laser desorption/ionization time-of-flight mass spectrometry. Curr. Med. Mycol. 2019, 2019, 22-26.

96. Gupta, A.K.; Foley, K.A.; Versteeg, S.G. New Antifungal Agents and New Formulations Against Dermatophytes. Mycopathologia 2017, 182, 127-141. [CrossRef]

97. Cantelli, B.A.M.; Bitencourt, T.A.; Komoto, T.T.; Beleboni, R.O.; Marins, M.; Fachin, A.L. Caffeic acid and licochalcone A interfere with the glyoxylate cycle of Trichophyton rubrum. Biomed. Pharmacother. 2017, 96, 1389-1394. [CrossRef]

98. Komoto, T.T.; Bitencourt, T.A.; Silva, G.; Beleboni, R.O.; Marins, M.; Fachin, A.L. Gene Expression Response of Trichophyton rubrum during Coculture on Keratinocytes Exposed to Antifungal Agents. Evidence-Based Complement. Altern. Med. 2015, 2015, 1-7. [CrossRef] [PubMed]

99. Bitencourt, T.A.; Komoto, T.T.; Massaroto, B.G.; Miranda, C.E.S.; Beleboni, R.O.; Marins, M.; Fachin, A.L. Trans-chalcone and quercetin down-regulate fatty acid synthase gene expression and reduce ergosterol content in the human pathogenic dermatophyte Trichophyton rubrum. BMC Complement. Altern. Med. 2013, 13, 229. [CrossRef]

100. de Abreu, M.H.; Bitencourt, T.A.; Franco, M.E.; Moreli, I.S.; Cantelli, B.A.M.; Komoto, T.T.; Marins, M.; Fachin, A.L. Expression of genes containing tandem repeat patterns involved in the fungal-host interaction and in the response to antifungals in Trichophyton rubrum. Mycoses 2020, 63, 610-616. [CrossRef] [PubMed]

101. Petrucelli, M.F.; Peronni, K.; Sanches, P.R.; Komoto, T.T.; Matsuda, J.B.; da Silva Junior, W.A.; Beleboni, R.O.; Martinez-Rossi, N.M.; Marins, M.; Fachin, A.L. Dual RNA-Seq analysis of trichophyton rubrum and HaCat keratinocyte co-culture highlights important genes for fungal-host interaction. Genes (Basel) 2018, 9, 362. [CrossRef]

102. Bitencourt, T.A.; Macedo, C.; Franco, M.E.; Assis, A.F.; Komoto, T.T.; Stehling, E.G.; Beleboni, R.O.; Malavazi, I.; Marins, M.; Fachin, A.L. Transcription profile of Trichophyton rubrum conidia grown on keratin reveals the induction of an adhesin-like protein gene with a tandem repeat pattern. BMC Genom. 2016, 17, 249. [CrossRef]

103. Petrucelli, M.F.; Matsuda, J.B.; Peroni, K.; Sanches, P.R.; Silva, W.A.; Beleboni, R.O.; Martinez-Rossi, N.M.; Marins, M.; Fachin, A.L. The transcriptional profile of Trichophyton rubrum co-cultured with human keratinocytes shows new insights about gene modulation by terbinafine. Pathogens 2019, 8, 274. [CrossRef]

Publisher's Note: MDPI stays neutral with regard to jurisdictional claims in published maps and institutional affiliations. 